\title{
The United States and \\ Inter-American Security, \\ 1889-1960
}


THIS PAGE INTENTIONALLY LEFT BLANK 


\section{J. Lloyd Mecham}

\section{The United States and \\ Inter-American Security, \\ $1889-1960$}

Published for the Institute of Latin American Studies,

The University of Texas

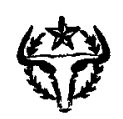

AUSTIN - UNIVERSITY OF TEXAS PRESS 
Copyright (C) I96 I by the University of Texas Press Fourth hardcover printing I965

First paperback printing 2014

All rights reserved

Printed in the United States of America

Requests for permission to reproduce material from this work should be sent to:

Permissions

University of Texas Press

P.O. Box 78 I 9

Austin, TX 78713-78I9

http://utpress.utexas.edu/index.php/rp-form

Library of Congress Catalog Number 6I-IO426

ISBN 978-0-292-76630-3, paperback

ISBN 978-0-292-7663 I-0, library e-book

ISBN 978-0-292-76632-7, individual e-book 
To my wife

MABEL OLIVE MECHAM

whose assistance, counsel, and inspiration are inadequately measured by the content of this volume. 
THIS PAGE INTENTIONALLY LEFT BLANK 